\title{
Why is English Green? The Preference for English on Environmental Discourse at a Thai University
}

\author{
Andrew Jocuns (แอนดริว โจคุนส์) \\ Thammasat University, Thailand \\ jocunsa@gmail.com
}

\begin{abstract}
This paper reports on an analysis of environmental discourse, or green discourse, in the linguistic and geosemiotic landscape of a Thai university. The overwhelming majority of green discourse signs at the university are in English and where they are bilingual (Thai and English), they tend to contain English in the preferred position. The language usage on the signage is also shown to be related to the sociolinguistics of globalization (Blommaert 2010) in terms of scale, indexical order, and polycentricity. These data are triangulated with data collected from walking interviews with students. The literature on ecolinguistics, the ecology of language and green discourse are reviewed within the context of the present study. The analysis focuses upon the geosemiotics (Scollon and Scollon 2003) of green discourse and how such discourse reflects patterns of the sociolinguistics of globalization.
\end{abstract}

\section{Keywords}

geosemiotics - linguistic landscape - sociolinguistics of globalization - global English-green discourse-ecolinguistics-scale-orders of indexicality-polycentricity

บทคัดย่อ

ภาษาอังกฤษในโลกสีเขียว: การเลือกใช้ภาษาอังกฤษในการสื่อสารด้านสิ่งแวดล้อมใน มหาวิทยาลัยไทย

บทความวิจัยฉบับนี้นำเสนอการวิเคราะห์ข้อความเรื่องสิ่งแวดล้อม (environmental discourse or green discourse) จากภูมิทัศนภาษาศาสตร์และภูมิสัญศาสตร์ (linguistic and geosemiotic landscape) ในมหาวิทยาลัยแห่งหนึ่งในประเทศไทย จากการศึกษาพบว่าป้ายที่มีข้อความเรื่อง

(C) ANDREW JOCUNS, $2019 \mid$ DOI:10.1163/26659077-02203002

This is an open access article distributed under the terms of the prevailing CC-BY-NC License at the time of publication. 
สิ่งแวดล้อมส่วนใหญ่เป็นภาษาอังกฤษ สำหรับป้ายที่มีข้อความสองภาษา (ไทยและอังกฤษ) ภาษา อังกฤษจะอยู่ในตำแหน่งที่เห็นได้ชัดกว่า การใช้ภาษาในป้ายยังแสดงให้เห็นถึงความเชื่อมโยงกับ ภาษาศาสตร์สังคมในยุคโลกาภิวัตน์ (sociolinguistics of globalization, Blommaert 2010) ในเรื่องของ scale, indexical order และ polycentricity โดยผู้วิจัยได้นำข้อมูลดังกล่าวมาเชื่อม โยงตรวจสอบกับข้อมูลที่ได้จากการสัมภาษณ์นักศึกษา โดยการพูดคุยสัมภาษณ์ไปพร้อมกับการ เดินตามจุดต่าง ๆ ในบริเวณมหาวิทยาลัย ทั้งนี้ผู้วิจัยได้มีการทบทวนวรรณกรรมเรื่องนิเวศวิทยา ภาษา (ecolinguistics) และการวิเคราะห์ข้อความในบริบทเรื่องสิ่งแวดล้อมภายใต้ขอบเขตของ การวิจัยชิ้นนี้ด้วย การวิเคราะห์ข้อมูลในบทความวิจัยฉบับนี้ มุ่งเน้นประเด็นเรื่องภูมิสัญลักษณ์ของ ข้อความในบริบทเรื่องสิ่งแวดล้อม และข้อความนั้นแสดงให้เห็นถึงลักษณะของภาษาศาสตร์สังคม ในยุคโลกาภิวัตน์อย่างไร

\section{Introduction}

This paper reports on research that explores the preference for English in the environmental discourse within the linguistic landscape at Thammasat University's Rangsit Center campus in Thailand. Over the last several years Thammasat University has created a campaign to become ecologically friendly. In so doing numerous signs around Thammasat's Rangsit campus that index some aspect of environmentalism have emerged including: discourse about recycling and the overuse of single use plastic. Although Thammasat University's Rangsit Center campus is home to many academic programs that are taught in Thai language, the code preference of environmental discourse in the linguistic landscape there is English. My analysis focuses upon a series of signs in recent public service announcement advertisement campaigns on campus that call attention to environmental issues such as: discourses of sustainable ecology and environmental friendliness. These signs often ask the reader to perform an action related to environmentalism. Such signage is also found in the built environment particularly in a new classroom building on campus, Social Sciences Building 2 ( $\mathrm{SC}_{2}$ ), which contains a series of signs illustrating how the building is an environmentally friendly space. I discuss how such discourses of environmentalism, or what I refer to here as green discourse, fall within Appadurai's (1996) vernacular globalization where dominant top down global discourses emerge within glocalized bottom up nuances, e.g. Thai English in green discourse. Using Kress and Van Leeuwen's visual semiotics (1996) and Scollon and Scollon's geosemiotics (2003), I argue that the code preference for English on bilingual and multilingual signage at Thammasat is reflective of the interplay between vernacular globalization on the one hand and the sociolinguistics of globalization on the other. I also discuss data collected from walking interviews with students that focus on two signs, Figures 1 and 2. My discussion and analysis relates the green English on the signage of Thammasat 
University's Rangsit campus to the sociolinguistics of globalization by focusing on three concepts that emerge: the sociolinguistics of scale, indexical order, and polycentricity. In sum the presence of English within green discourse is reflective of globalization.

\section{Ecologies of Language: The Ecology of Language, Ecolinguistics, and Green Discourse}

Discourses about the environment, sustainability, ecology, and green-ness fall under the paradigm of ecological linguistics. Ecolinguistics has many forms of analysis and theories. Ecolinguistics as a field of research emerged in the 1970's closely related to the developing environmental movement at the time which proposed action and awareness on issues of the environment. Ecolinguistics can be defined as expanding linguistics, more so sociolinguistics, to include not just the social context of languages but also the environmental context within which they are situated. Language has been identified as being closely related to the environment, and language loss has been noted to effect biodiversity to the degree that linguistic knowledge about the world around us, such as ethnobotany, is lost when languages disappear (Nettle and Romaine 2000). An ecolinguistic stance presupposes that there is an equilibrium between language and the world in which that language is situated.

Both LeVasseur (2015) and Chen (2016) have identified three approaches to ecolinguistics: a Haugenian approach, a biolinguistics approach and a Hallidayan approach. However, there are a number of problems with such a distinction. Left out is the approach developed by the social psychologist Rom Harré (Harré, Brockmeier and Mühlhäuser 1999) formulated as green discourse. In addition, Chen (2016) leaves out an important point, that a lot of the terminology used to describe the seemingly separate strands of ecolinguistics is the same. For example, the terms ecology of language and language ecology emerge in all three strands with slight differences in how the term is used. The use of the term biolinguistics is derived from Nettle and Romaine (2000) who coined the term biolinguistic diversity to refer to how languages, just like biological species, are adaptive to their respective environments. The reference to biolinguistics is also problematic because biolinguistics is itself a subfield of linguistics which also includes aspects of human biology and language evolution. Biolinguistics is a separate field of study from ecolinguistics with roots in the Chomskyan paradigm (Jenkins 2000; Sanz, Laka and Tanenhaus 2013; AlMutairi 2014; Boeckx and Martin 2016). For the purposes of the present discussion I use the term green discourse to refer to the variety of stances about the discourse of environmental activism including: sustainability, environmental 
friendliness, saving the earth, and language ecology. Using the term green discourse for the present study is a means overcoming the paradigmatic nuances of the use of overlapping terms.

In the following sections I situate the discussion of environmental signs in the linguistic landscape of Thammasat within the context of several paradigms of linguistics: Hallidayan ecolinguistics, Haugenian ecology of language, language ecologies, and green discourse. In so doing I emphasize how these paradigms are related and important to consider in the study of linguistic landscape.

The Hallidayan (2001) approach to ecolinguistics has noted a fundamental relationship between language and humanity's destruction of the environment. The idea that Halliday posed was that language can be used in a manner that has deleterious effects upon the environment. By employing the analytical toolkit of systemic functional linguistics, researchers who use Hallidayan ecolinguistics can identify and prevent the linguistic influence of environmental damage. Hallidayan ecolinguistics has also emerged in critical discourse analysis (Alexander and Stibbe 2014; Stibbe 2014) which has taken on not only a critical analysis of environmental texts but an advocacy role as well.

\section{$4 \quad$ Language Ecologies}

One of the earliest references to the ecology of language was developed by the linguist Einar Haugen. Haugen's (1972) approach to the ecology of language presupposes a strong mutual relationship between language, society, cognition, and the environment. The study of language as whole, he argued, should take into account these various symbiotic relationships. Haugen's sense of an ecology of language permeates nearly all discussions of ecolinguistics including studies of linguistic landscapes (e.g. Hult 2009).

Intimately related to the ideas that make up ecolinguistics is the ecology of language which emerged as a paradigm around the same time as ecolinguistics, and as a term, has occasionally been used interchangeably with the ideas that make up ecolinguistics. This approach is the most widespread encompassing several disciplines that focus on language policy and language planning: linguistic anthropology, sociolinguistics, and other subdisciplines. Smalley's (1994) discussion of language policy and the ecology of languages 
in Thailand is one notable example. The concept of the ecology of language has persisted up to the present by linguists such as Landry and Bourhis (1997). Here the idea of ecology and language situates language within a specific area of the world. An issue with this sense of ecology is that the area of the world in question is often ill-defined itself and is usually urban in nature. The ecology of language in this sense also refers to language in the world around us and has been used as one of the defining characteristics of the paradigm of linguistic landscape studies. The idea here is that linguists who study language policy and language change can get a sense of the linguistic vitality of an area by observing the languages that are present within its linguistic landscape. The ecology of language thus is also referring to multilingual situations where multiple languages are interacting with one another and having effects upon one another. There is a lot that has been learned from such studies, Huebner's (2006) study of Bangkok is a case in point where an emerging variety of Thai English was identified, and that Chinese, which had been a language of wider communication in Bangkok, was losing status and being replaced by English.

The notion of ecology has also been applied to the context of sociolinguistic interaction, for example Erickson (2004; 2015) has used the term ecology to index contexts of talk in educational settings. Yet another approach to the ecology of language and linguistic landscape is more fitting to the present study, more specifically Francis Hult's (2009) which uses the methods of nexus analysis (Scollon and Scollon 2004; 2007) to examine the linguistic landscape. The relevance to the present study is that the signs which make up green discourse at Thammasat are not isolates. They exist among other language that is used and are in circulation among the everyday discourse of students enrolled at the university.

\section{5}

\section{Green Discourse}

Whereas eco-linguistics and language ecology have been endeavors purely from the study of linguistics, the study of green discourse (Mansvelt 2011) is quite broad in its academic scope. As Mansvelt (2011) has argued, green discourse is a stance within the broader field of environmentalism in which notions of environmental protectionism take a role in economic development. Green discourse overlaps with a number of disciplines. Harré et al have analyzed the different positions that are taken up in environmental discourse from both sides of the debate arguing that environmental studies require more attention to the discourses that make them up (Harré, Brockmeier, and Mühlhäuser 1999). 
Green discourse falls within the notion of Foucauldian orders of discourse, James Gee's discourse with a capital "D" (Gee 2015), as well as Scollon and Scollon's discourse system (Scollon, Scollon, and Jones 2012). This is evidenced in how green discourse has an ideological value that different social actors place upon it and that there are ways of speaking about green discourse that includes language that indexes aspects of the environment. Dryzek (2013) argues that the ideas that make up green discourse are both radical and creative, radical to the degree that its adherents reject the neoliberal ideas that fill modern industrial capitalist societies and creative to the degree that they attempt to propose solutions. Social actors who align themselves with green discourse take the stance that there is a global crisis which is both social and environmental in nature. Proponents of green discourse are advocates of developing educational resources as one means in which to create a sense of agency among social actors which can affect change to such an extent that it has the potential to thwart the present social and environmental crisis.

\section{Green Discourse and the Sociolinguistics of Globalization}

The ideas within the texts that make up the environmental messaging at Thammasat University indexes both green discourse and the language of globalization. Many of the signs are educational in scope and reflect green discourse through such terms and phrases as: no single use plastic, save the world, as well as the use of the term green, e.g. Green Canteen (see Figures 15, 16, 17 , and 18 below). Green discourse, ecolinguistics and the study of language ecology are all embedded within larger discourses of globalization. There are several features of green discourse that make it a part of the sociolinguistics of globalization. Blommaert's terminology on the sociolinguistics of globalization (2010) is helpful in discussing how green discourse is both globally and locally situated. Such concepts include: scale, orders of indexicality, and the polycentricity.

\section{Scale}

Scale refers to the layered-ness of social practices and, as Blommaert (2007, 2015) notes, the term was borrowed from geography as a means of combining the notions of time and space. Scales are layered in a similar manner to the notions of micro and macro in sociolinguistics. Lower scale social practices 
are localized and fleeting and higher scale social practices are timeless and global. Linguistic tokens on a higher scale are homogenous, objective and decontextualized. In contrast, linguistic tokens on a lower scale are heterogenous, diverse, subjective, and context dependent. An important consideration in sociolinguistic scale is what Blommaert notes as scalar jumping or scalar mixing, where items are represented as being both local and global. The green discourse catchphrase "think globally and act locally" certainly represents such scalar-mixed reasoning. Green discourse at TU often emerges in the manner of scalar mixing where ambiguous phrases are laid out with images in such a manner that they represent scales which are meant to be global and local at the same time. For example, the text say no to single use plastic is a token that is high scale as it represents an objective and decontextualized stance about the environment. Placing the Thammasat seal on the sign, or Thammasat's branding for the campaign, Thammasat People \& Sustainability or Thammasat Smart City, localizes the token. But in fact, these tokens are homogenized in such way that it is difficult to discern how they represent either global or local discourse. One of the reasons for this has to do with the presence of global English, or machine translated English, on some of the signs.

\section{8}

\section{Orders of Indexicality}

The notion of orders of indexicality is derived from Silverstein (2003) who noted how different registers index different orders of social meaning at three levels of order. A first order indexicality occurs when indexical links between ways of speaking and social groups are not yet defined, but are identifiable by sociolinguists. A second order indexicality emerges when a register is linked to a social group and a third order involves the evolution of the register such that it could be articulated in performance by speakers who are not members of the social group in question. The green discourse at TU that I have collected from the linguistic landscape index first and second order indexicality to the degree that linguistically they can be tied to forms of English (global English, Thai English, green discourse) and at the same time they index groups of people who are environmentally friendly. Note also that this is related to sociolinguistic scale. Thai English indexes the local, it is contextualized and locally situated representing a lower scale. At the same time, Thai English is a form of global English and the signs which emerge at Thammasat regarding the environment in general reflect globalization. In both cases, global English and general 
references to the environment, the linguistic tokens represent decontextualized global discourses at a higher scale. In this manner, orders of indexicality are related to scale.

\section{$9 \quad$ Polycentricity}

The third concept relevant to our discussion of the sociolinguistics of globalization and green discourse is Blommaert's (2015) notion of polycentricity referring to how it is that there are multiple centers of power and authority. When we hear particular registers or voices in use, we are immediately invoking different senses of power, authority and relationship. Goffman (1981) referred to such interactional shifts as shifts in footing. Polycentricity is related to footing but argues that with shifts in footing are also shifts in relationship status. Shifts in relationship status are also related to power and authority. In terms of green discourse, we have to ask whose voice is being represented, who is the voice of power and authority that is being responded to through such signage?

One manner in which green discourse is situated globally is through the presence of English where it appears as a global language. Blommaert notes that some linguists who take a strong linguistic ecology position often assume that English immediately threatens other languages. While on the surface the homogenous nature of the language that is used on green discourse signs pose little threat to linguistic ecology, the Hallidayan approach to ecolinguistics suggests that how texts are constructed can lead to misunderstandings, negligence or deleterious behavior (Halliday 2001; Stibbe 2014). One of the issues with the English on some of these signs is that the English is ambiguous and it is not always clear what the actual meaning is. The signs are awkward to the degree that they are vague using scientific language to inform us of facts that are not immediately relevant. On the other hand, this scientific green English is written for a glocal audience who mostly speak a glocalized form of English, Thai English.

10 Methods

The data consists of images captured using smartphones and were collected between August 2018 and December 2018. The images were collected by the author and students in the class World Englishes during semester 12018. 
A total of 48 images were identified as pertaining to the topic Green English. Well over a hundred images were collected during this time but only 48 were relevant to the present analysis. The images that were captured by students were used for classroom discussion and analysis. Of those 48 there are 4 which are not of text-based signage, but are images of objects in the material world which reflect green discourse. Though this sample size is small it reflects more recent trends toward the emphasis on Green discourse at Thammasat reflective also of a specific sample of the linguistic and geosemiotic landscape.

In terms of analysis, multimodal analysis software was used to accurately collate codes used to analyze the text, text orientation, and code preference on the images. Codes were developed in an emergent nature during the coding process. A total of 14 codes were used in the analysis of which 11 were deemed reportable for the present discussion. These codes include: arbitrary statistics, Chinese language, English language, English code preference, English only, hybrid language/translanguaging, left/right text and graphic orientation, Thai language, Thai code preference, top/down text and graphic orientation, and vague text. Arbitrary statistics refers to statistics that were present on the signs that was used in an ambiguous manner such that the statistic used was difficult to discern its relevance. Chinese language was used where Chinese emerged on a sign. English language as used when English emerged on a sign. English code preference refers to signs where English was the preferred code. English only was used to code signs where English was the only language on the sign. Hybrid language/translanguaging was used to code signs where there were multiple languages and the languages were not translations but were reflective of hybrid language use where, for example, there was Thai text followed by English text and the English was not a translation of Thai. Left right orientation was used to code signs that had a left/right text and image vector following Kress and Van Leeuwen (1996) and Scollon and Scollon (2003) to determine the preferred code on a sign where left was new and right was given, left was considered to be the preferred code. Thai was used to identify signs that contained Thai language, and Thai code preference was used to code signs that had Thai language in the preferred position. Top down orientation was used to code signs that had a top/down text and image vector where the language in the top position is identified as being the preferred code on the sign. Vague text was a code used to identify signs that had text that was difficult to parse, had ambiguous syntax, missing determiners, subjects and/ or missing or misuse of other grammatical devices. Table 1 is a breakdown of the codes and findings. 
TABLE 1 Descriptive statistics based on codes used.

\begin{tabular}{lr} 
Code & $\#$ \\
\hline Arbitrary statistics & 7 \\
Chinese & 1 \\
Bilingual & 10 \\
English & 38 \\
English code preference & 38 \\
English only & 20 \\
Hybrid language/Translanguaging & 4 \\
Left/Right orientation & 3 \\
Thai & 18 \\
Thai Code Preference & 10 \\
Top/Down orientation & 38 \\
Vague Text & 12 \\
& \\
\hline
\end{tabular}

\section{English Preference in Green Discourse at Thammasat}

In their (2003) discussion of geosemiotics Scollon and Scollon note relationships between place and code preference based in part upon Kress and Van Leeuwen's visual semiotics (1996). Indexicality, specifically the semiotics of place, are integral to the analysis of code preference geosemiotics. Signs index things, ideas, place, and space in the world and when we examine the code preference of signs, an analysis of the information structure that makes up those signs can reveal relationships of code preference. As Scollon and Scollon note multilingual signage reveals a choice system which can help us to understand code preference (2003: pp. 116-128). In relation to code preference information structure is one way that we can analyze which languages are chosen to be in the preferred position. This information structure works as follows: left/right where left is given information and right is new; top/down where top is information which is ideal and down where information is considered real; and center/periphery where the center is the focal point of the image (Kress and Van Leeuwen 1996: pp. 185-229). In bilingual signs, languages which are in the left (given) and top (ideal) positions are languages which are positioned in a preferred status (Scollon and Scollon 2003). In addition, size of font as well as the amount of text in a given language may also be used to determine code preference. 
In the analysis of these images information structure was taken into consideration examining how the information was orientated in either a left/right or top/down text and graphic orientation. In so doing languages which were in the left/right (given/new) position as well as the top/down (ideal/real) position were identified in order to determine code preference. Of the 48 images that were captured 38 of them were orientated in the top/down configuration and only 4 were in a true left/right configuration. An overwhelming 38 of the signs were oriented with English in the preferred position, with English being in the top or ideal position, 18 of those signs were bilingual English and Thai, and 10 had orientations with Thai in the preferred position. It should also be noted that while many of the bilingual signs had English in the ideal position with a larger font, several signs had more Thai text on them. Many of the signs were captured from a new building, were all in English and were designed as infographic types of images. The sections that follow analyze the specifics of the text and image relationships, offering examples of the types of green discourse that have emerged in the geosemiotics of Thammasat University.

The images in Figures 1, 2, 3, and 4 were captured from a new classroom building that opened in August 2018 known locally as SC2 (Social Sciences Building 2). The building contains many infographics that index how the building

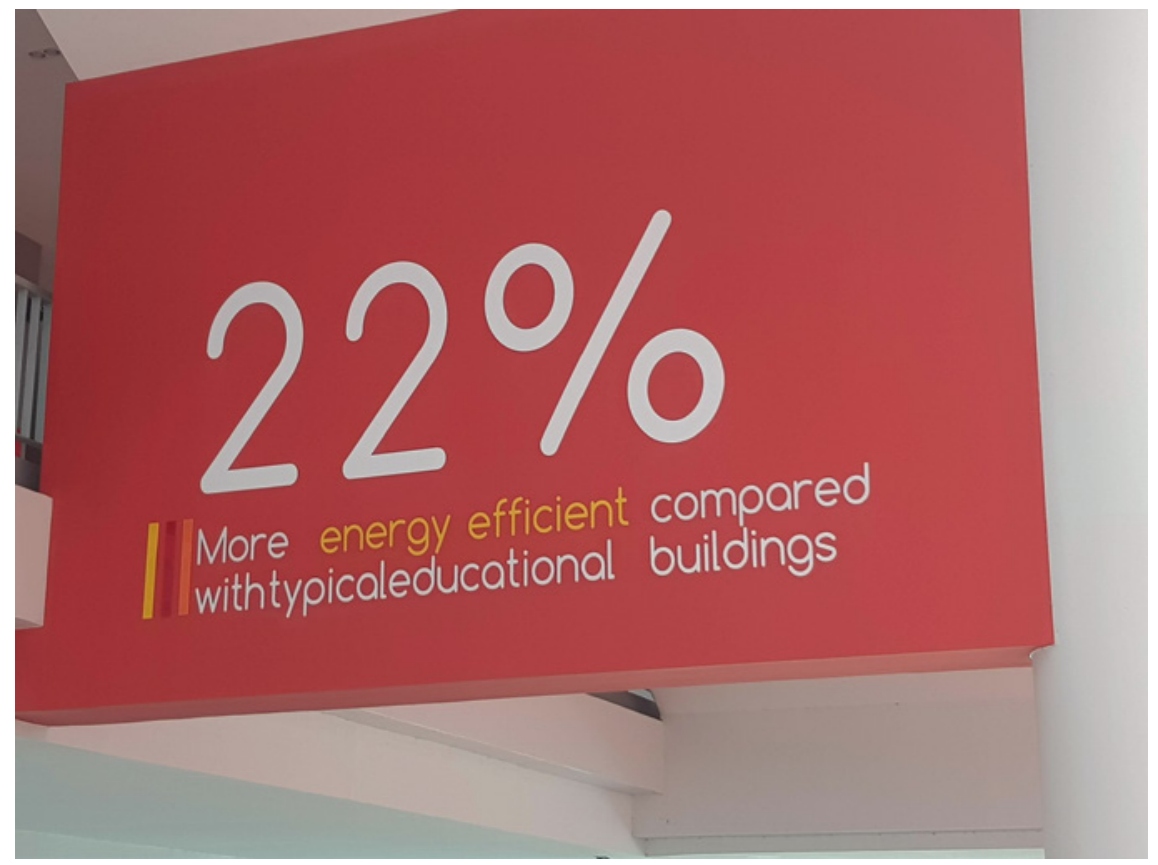

FIGURE $1 \quad 22 \%$ More energy efficient compared withtypicaleducational buildings 


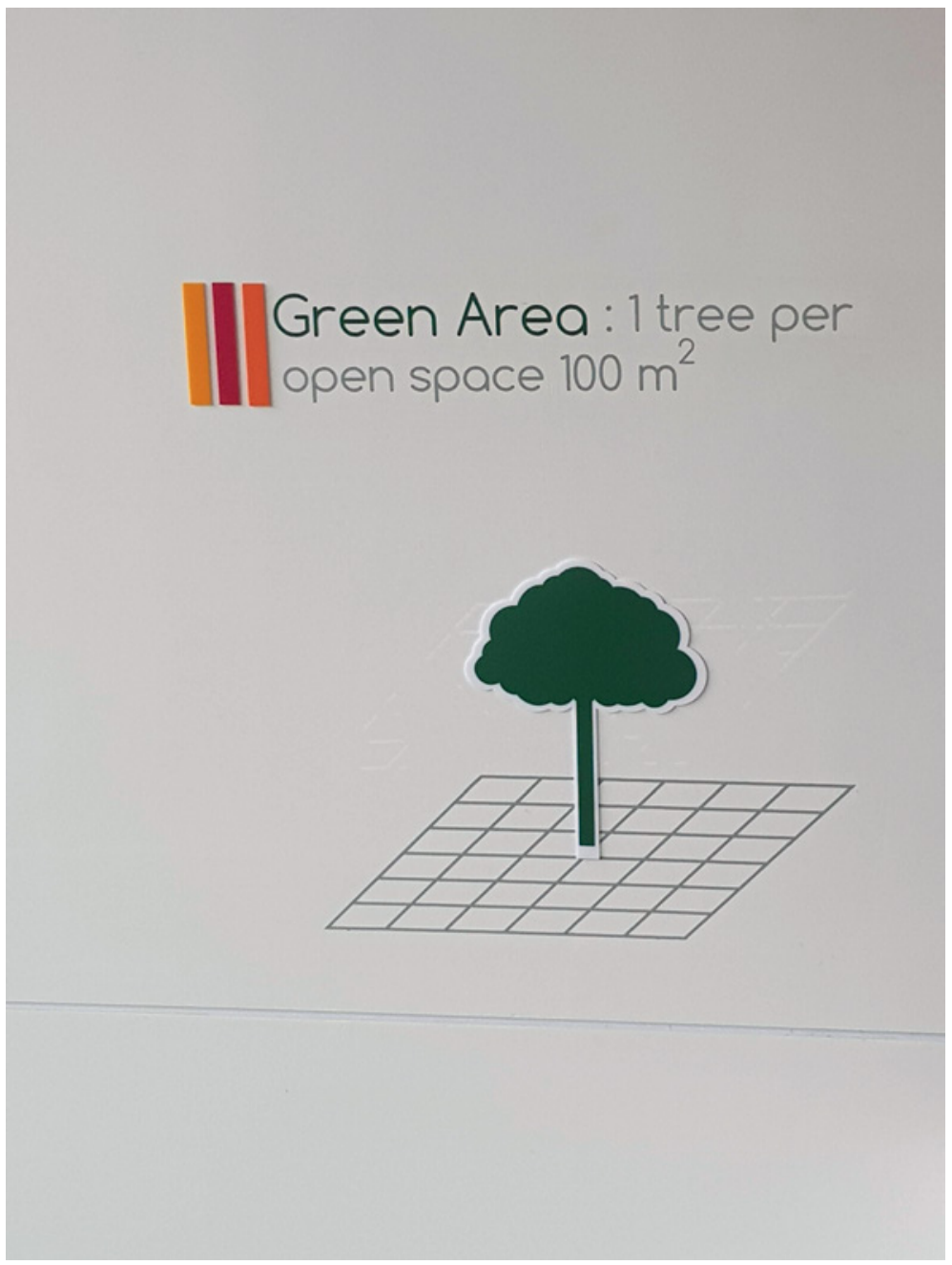

FIGURE 2 Green Area: 1 tree per open space $100 \mathrm{~m}^{2}$

is environmentally friendly which also indexes green discourse through references to environmentalism and sustainability. The signs suggest that this building is a space situated within the discourse of environmentalism which reflects the various functions that make the building environmentally friendly and self-sustainable. This is accomplished by using several signs that fall within the category of situated semiotics in the Scollon and Scollon (2003) framework, namely through emplacement and inscription. Emplacement refers to how it is that a sign's meaning is based upon where it is located. Inscription refers to the physical material of language on signs. The emplacement in relation to the 


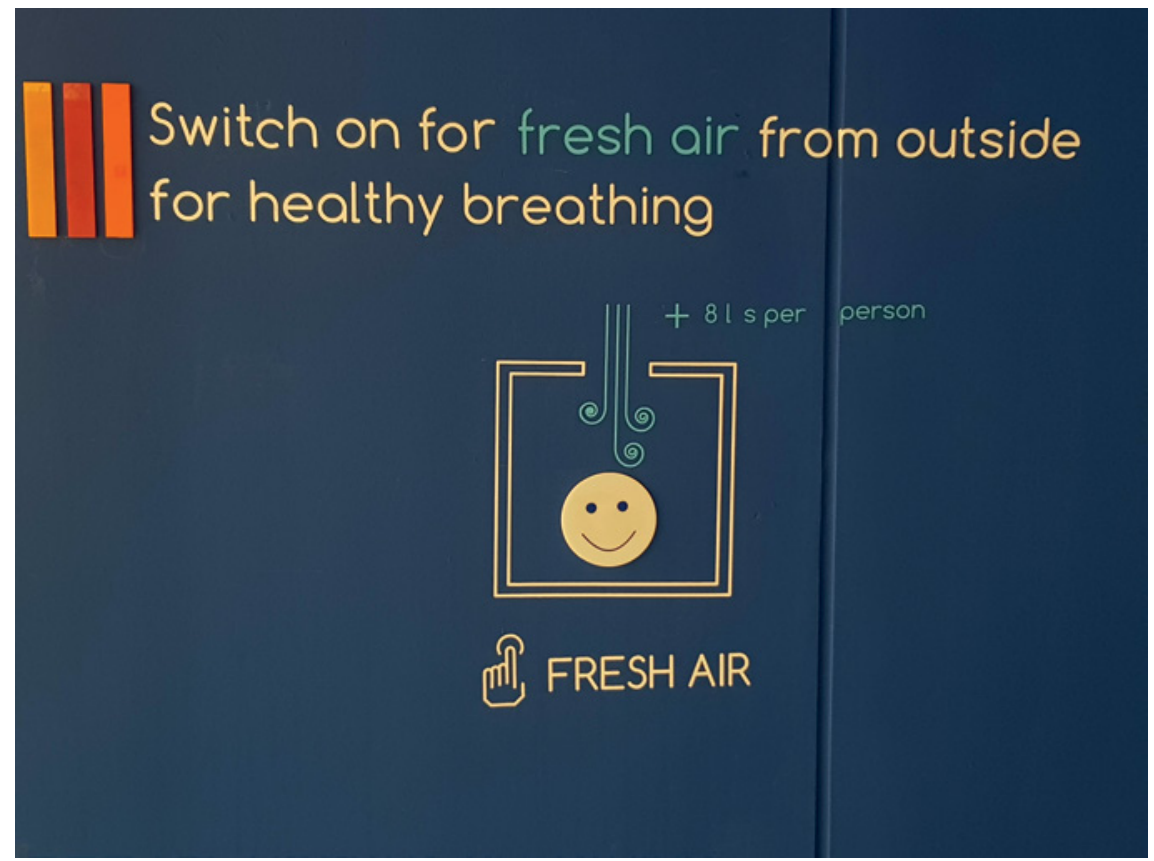

FIGURE 3 Switch on for fresh air from outside for healthy breathing

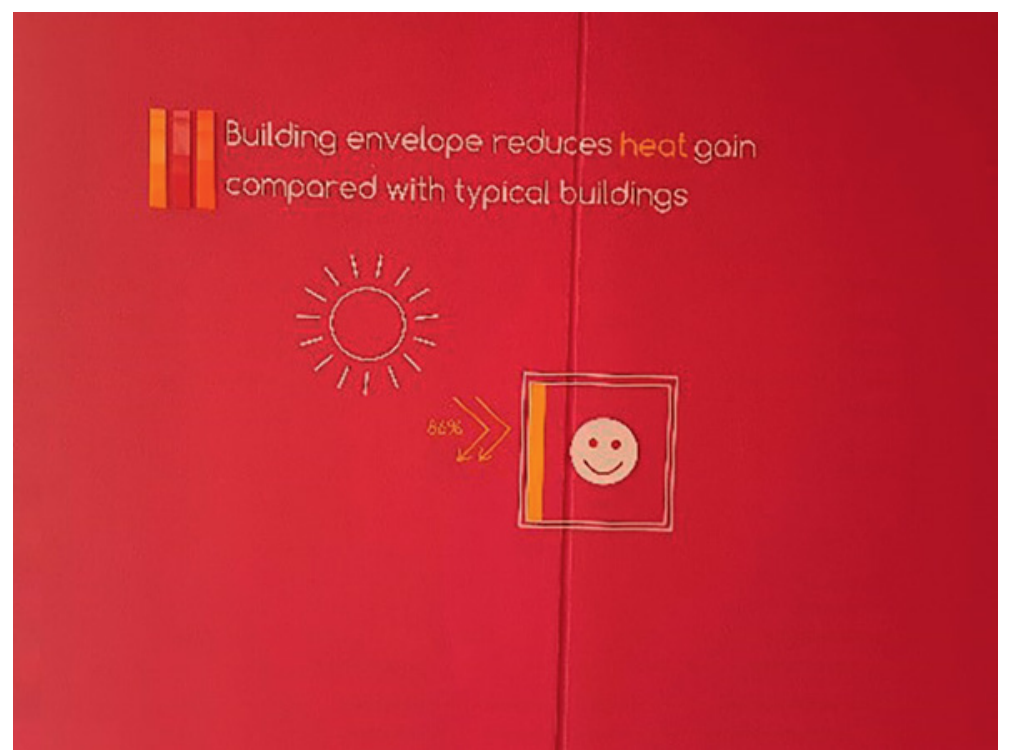

FIGURE 4 Building envelope reduces heat gain compared with typical buildings 
signs about sustainability and green discourse in $\mathrm{SC}_{2}$ is based upon how these signs are only relevant to the building that they are located in. There are some notable indexical spatial referents missing from the signage, for example Figure 4 may be more meaningful, and situated, if the indexical referent this was placed before the word building. These signs and the green discourse messages that they convey are painted on the on the walls and pillars within the building. In some cases, the texts on these messages are embossed (Figures 2, 6, 8), in both cases such inscription practices emphasize the permanence of these signs in terms of their materiality - these texts are meant to endure.

Looking a little more specifically at the text on these images there are some notable patterns. Beginning with the image in Figure 1 which notes: $22 \%$ more energy efficient compared withtypicaleducation buildings. The sign uses an arbitrary statistic to situate the building in terms of its efficiency. The use of offset yellow to highlight energy efficient is perhaps an attempt to index what $22 \%$ is referring to. Withtypicaleducational buildings is interesting in terms of the typographic error of the spacing of the words as well as the fact that it lacks a specific referent for, typical educational building? The reference to typical buildings in the image Figure 4: Building envelope reduces heat gain compared with typical buildings. The referents typical building and typical educational building here are vague. This misconstrues what the $22 \%$ is being comparing to: other buildings at the university, classrooms in general, a tutor's space, or a cram school? All fall with in the category of typical educational setting. Pragmatically if we consider the notion of scalar implicature the scale of the item is a very large category that can include any number of spaces. This use of an arbitrary statistic can index high scale as it is not clear what the comparison is to. Note also again the typographic error, the overgeneralization of the modifier for fresh air in Figure 3, the misuse of spacing between the colon and text in Figure 2. All of these index glocalized Thai English in particular the typographic errors because Thai orthography contains no punctuation and may have little to no spacing between words within a sentence. Reflective of what Jaworski has referred to as Globalese (Jaworski 2015).

Figures 5, 6, 7 and 8 are images that capture green discourse in SC2 as well. These images also have similar issues concerning the localized form of English but are more representative of the infographic type of texts that are being used to index, and situate this building within the context of green discourse as a global phenomenon.

The image in Figure 5 indexes sustainability, the plants are watered using rainwater collected in a tank in the building. Waste is separated and every effort helps, the notion that there is an effort underway and that the building is helping in the sustainability effort index the human agents who perform 


\section{This rainwater tank used
for watering plants \\ around building}
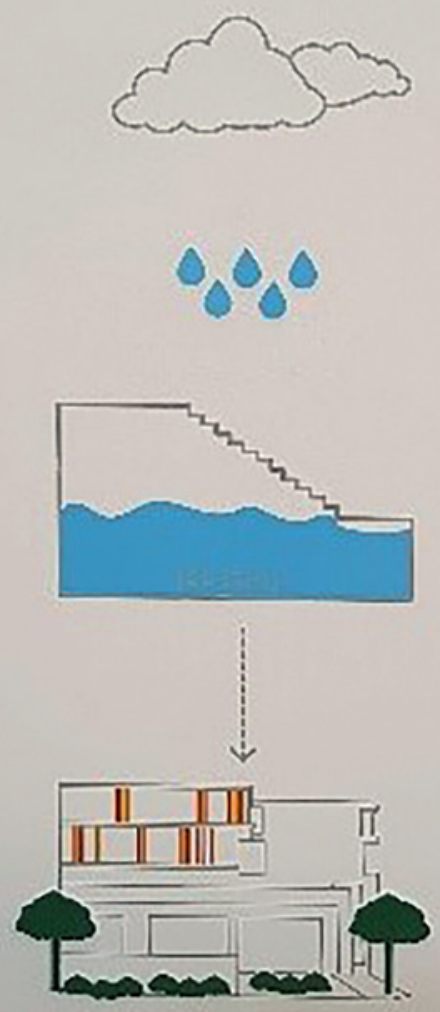

FIGURE 5 The rainwater tank used watering plants around building

social actions to meet the demands of green discourse. The image in Figure 7 contains an infographic that has similar issues of reference noted in Figure 2. What is the ideal amount of natural light? Does $10 \%$ refer to the amount light that the building filters or the amount of sunlight that is healthy for humans? In both Figures issues of scale, indexical order and polycentricity are apparent. In terms of scale the vagueness and ambiguity of the language used to index green discourse is of a higher scale, it is homogenous, impersonal, collective, objective and timeless. There are two indexical orders at work. A first order is 


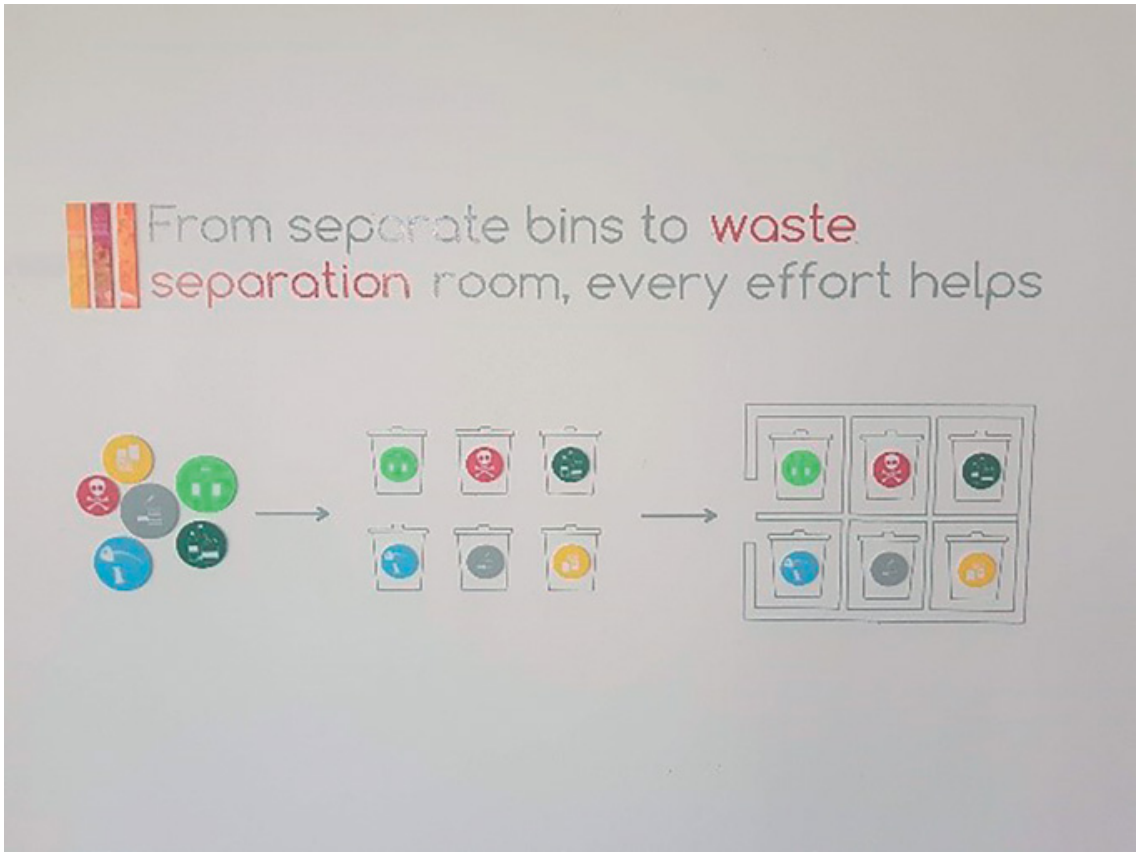

FIGURE 6 From separate bins to waste separation room, every effort helps

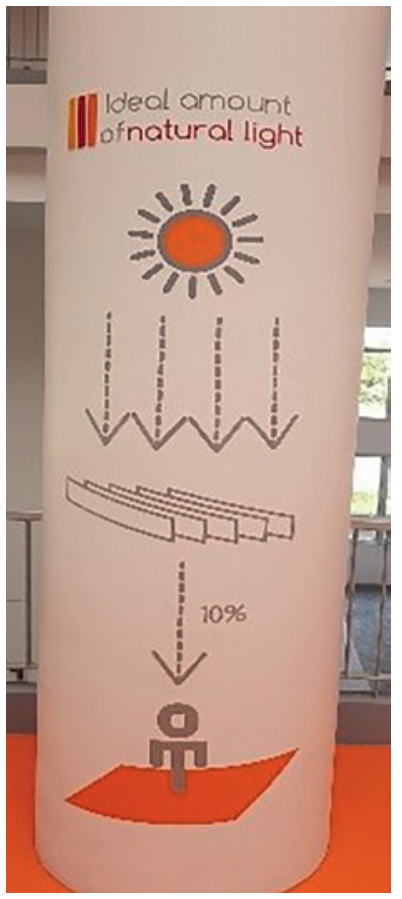

FIGURE 7

Ideal amount of natural light 


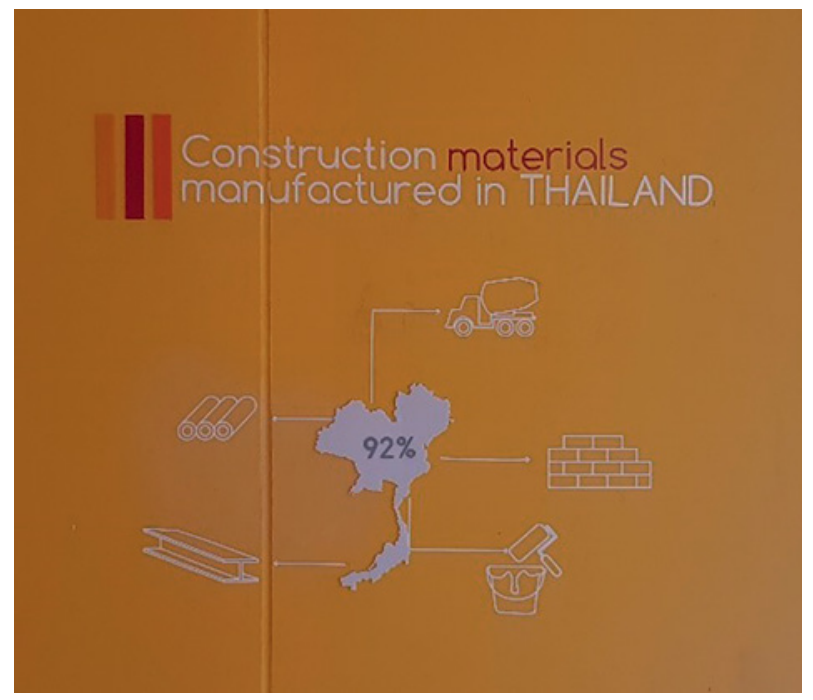

FIGURE 8 Construction materials manufactured in THAILAND

where we can identify some features of a glocalized form of English through over generalized modifiers and typographic errors which index Thai orthography. We can observe a second order through the reference to a globalized discourse of environmentalism and sustainability. In terms of polycentricity we have to ask whose voice is the voice of authority, whose voice is represented, whose voice is meant to receive these messages as well? The voices represented can be a globalized green discourse as well as the local efforts for sustainability. The glocal voice of authority is represented in these images through the manipulation of color scheme: yellow and red are the colors of Thammasat and their use in these signs indexes and inscribes the local authority of the Dome. The Dome is a symbol of Thammasat University, it is a building with a dark pointed shape, which is said to be the shape of a pencil so that students can write their future, or the sky is the limit. The Dome is used in many signs on campus.

Figures 9, 10,11, 12 and 13 are images of signs that reflect Thammasat's efforts towards sustainability. An interesting feature of these images is the use of the Thammasat logo, colors, and the Thammasat motto. The Thammasat motto, Thammasat where we learn to love the people, can be found throughout the linguistic and geosemiotic landscapes at Thammasat with occasional variations. What we observe in these images are intertextual references to the motto with lexical links to words (e.g. people, the phrase "where we learn...") within it. In addition, the use of the Dome image as an icon also creates an intertextual 


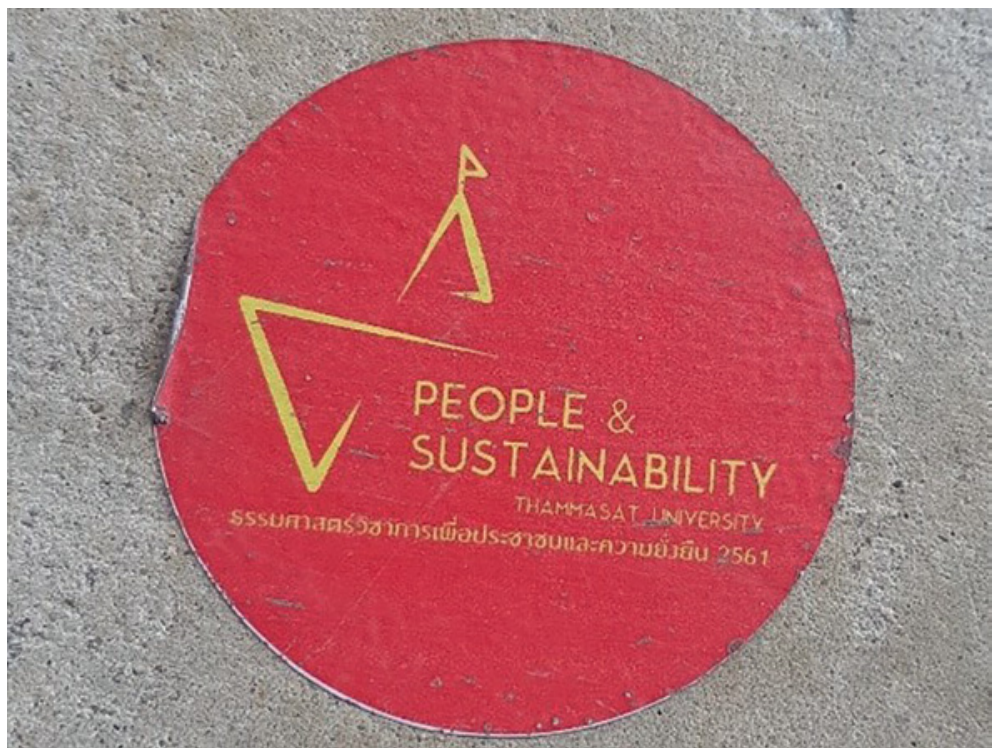

FIGURE 9 People \& Sustainability

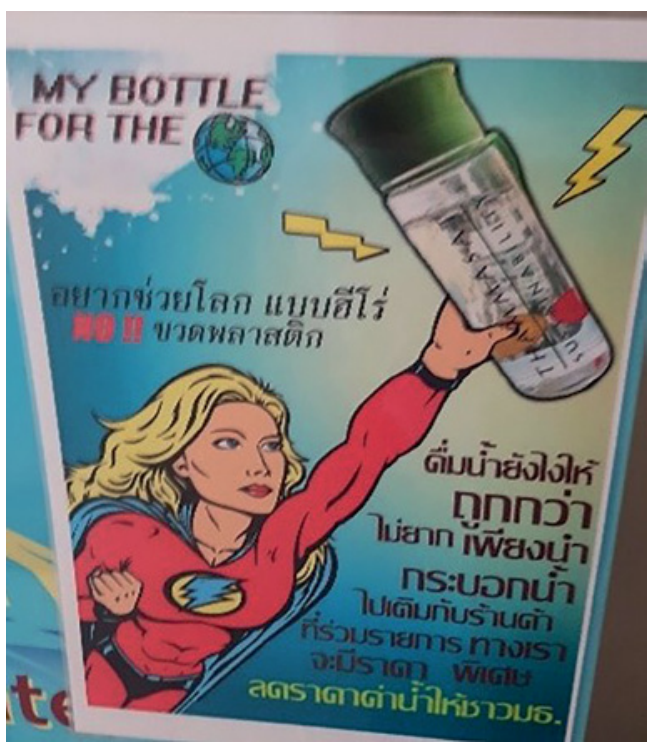

FIGURE 10

My bottle for the Globe

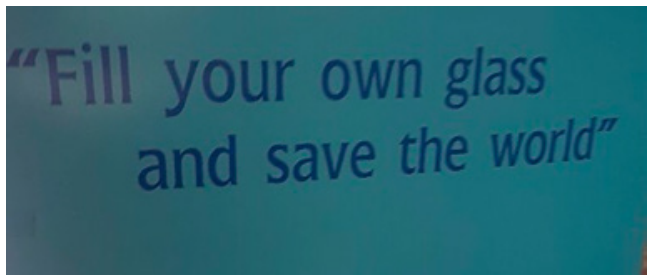

FIGURE 11

"Fill your own glass and save the world" 

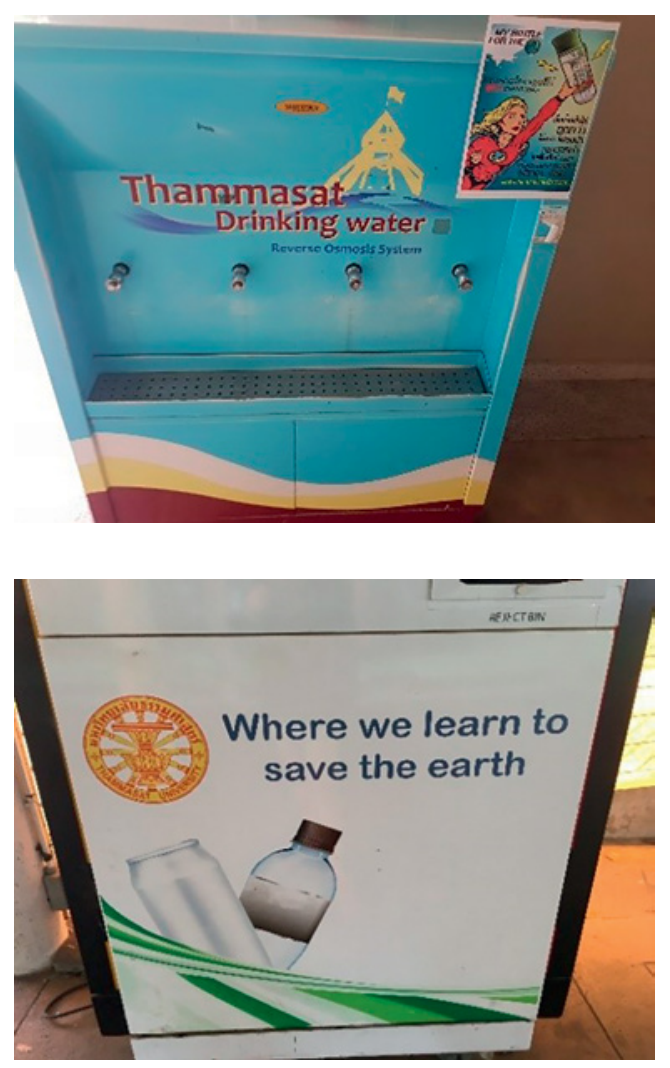

FIGURE 12

Thammasat Drinking water Reverse Osmosis System
FIGURE 13

Where we learn to save the earth

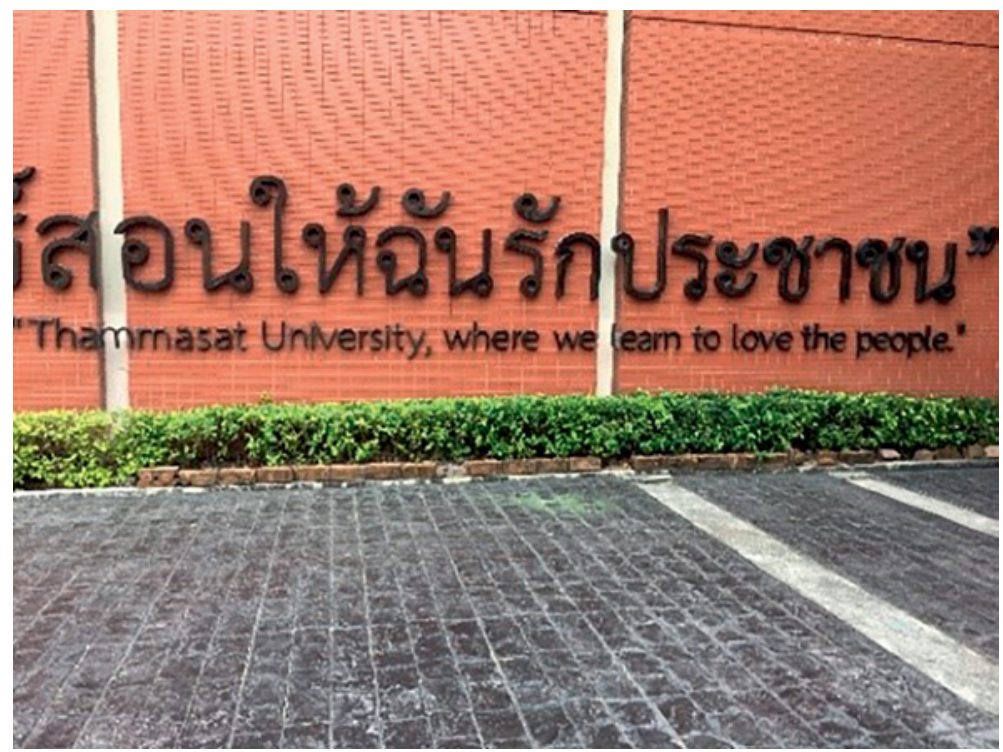

FIGURE 14 Thammasat University, where we learn to love the people 
link, and indexes the local authority that sanctions the mottos represented in the green discourse on these signs.

The intertextuality (references and relations to other texts (Urban and Silverstein 1997)) can also be perceived as interdiscursivity (references to other large scale discourses (Fairclough 1992)) to the degree that they index both discourses about environment as well as discourses about the ideology of Thammasat: serving or loving the people, serving or saving the earth (Figures 10, 11, 12, 13). Resemiotization (Iedema 2001) is the process of recreating a text in a different mode, for example taking a story and creating a video animation of it. We can also observe how these instances of green discourse are resemiotizations using different modes and modalities to extend the meanings of the motto. The motto is resemiotized not in Thai but in English. Yet looking at the how the motto is displayed on the building in Figure 14, we can see how Thai is used in the motto in the preferred position with also a larger font. The use of English plays on Thammasat's motto for Green Discourse illustrates the preference for English in Green Discourse.

The images in Figures 15, 16, 17, 18 and 19 concern two themes to emerge from the data set: one with regards to single use plastic, the other with the creation

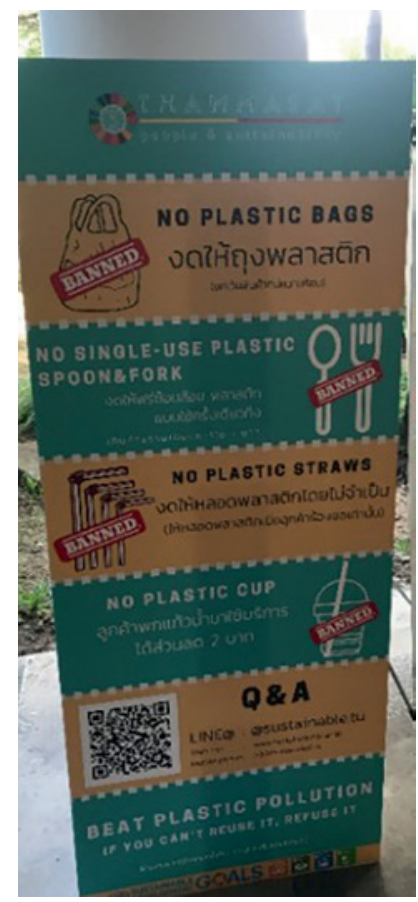

FIGURE 15 Thammasat people \& sustainability

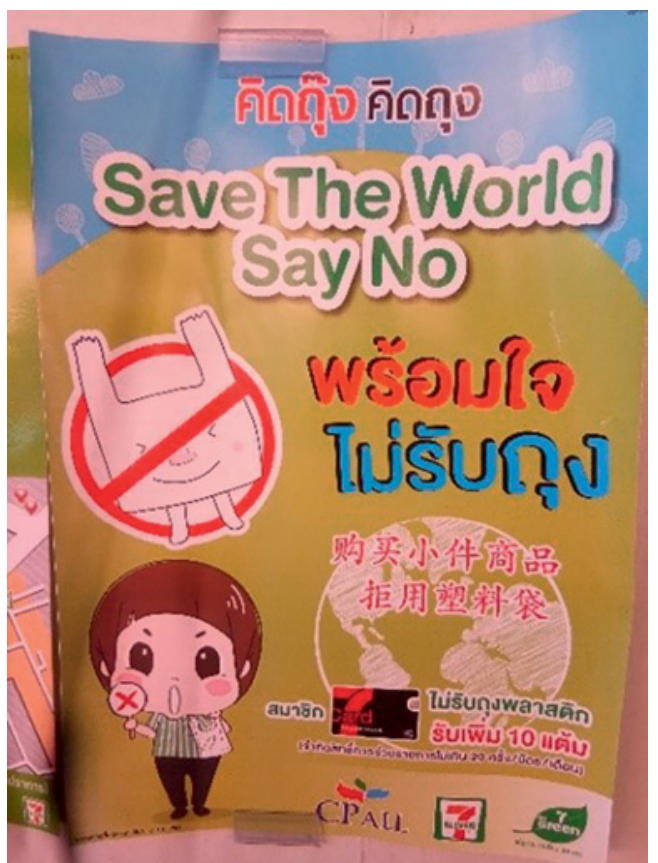

FIGURE 16 Save The World Say No 7-11 sign 

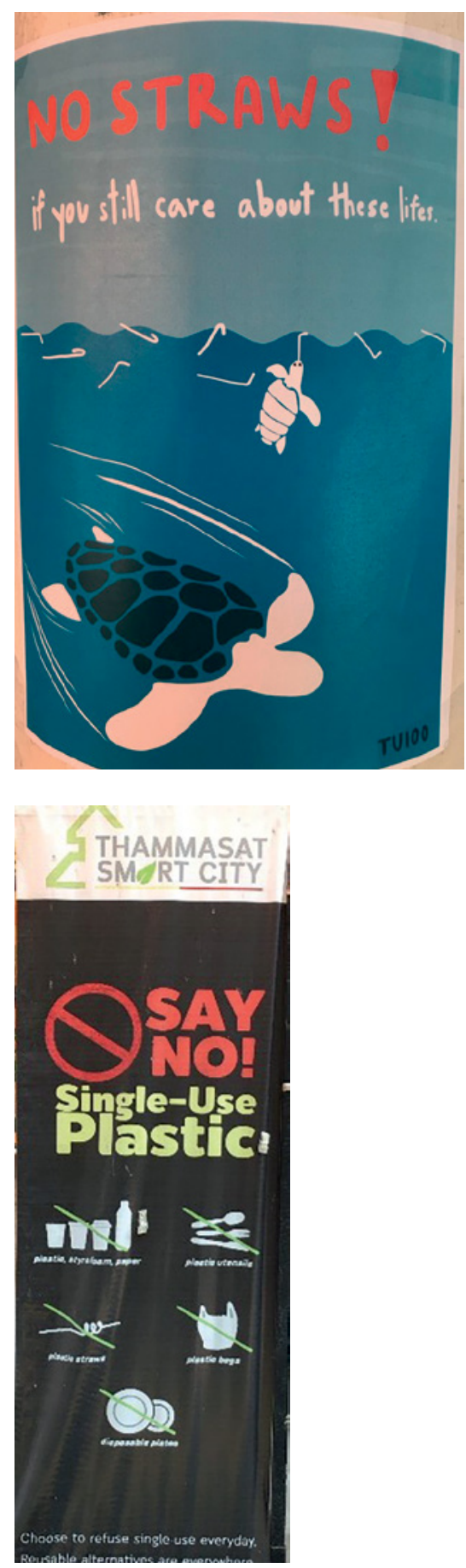

FIGURE 18 Thammasat Smart City, SAY NO! Single-Use Plastic
FIGURE 17

TU 101 No Straws! If you still care about these lifes

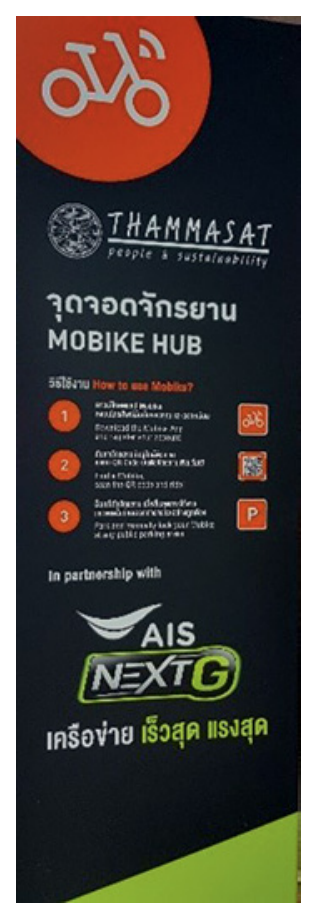

FIGURE 19 Thammasat People \& Sustainability rentable bike sponsored by AIS 
of a logo for Thammasat's environmental and sustainability campaign. The image in Figure 17 was made by students in a freshman course, TU101, as a part of their course project. Interestingly many of the signs that are made from TU101 emerge as bilingual and multilingual signs on campus. The images in Figures 16 and 19 are both bilingual signs and are also instances of corporate discourse. Figure 16 is a $7^{-11}$ sign is that was created in three languages, Thai, English and Mandarin. Figure 16 is one of four signs that was coded hybrid language/ translanguaging. The sign was designed in a translanguaging manner (Wei 2018) in which the languages on the sign are not translations of one another. Rather it reads as a whole text in English as: Really remember (Thai), save the world say no, don't' take the (plastic) bag, (Mandarin - don't take bag for small things) and then it mentions that you can receive more points for not using the plastic bag (Thai). This instance of translanguaging is interesting to consider in terms of language choice. Thai and English signs are found all over Thammasat's campus, but there are very few signs in Mandarin. Why use Mandarin to mention something important concerning Green Discourse? The entire text is about not using plastic bags, but the Mandarin that emerges is quite specific, concerning taking a bag for small items. As Scollon and Scollon (2003) have noted in multilingual signs with more than two languages as in Figure 16, it can be difficult to determine which language is preferred. Do we assume Thai is preferred because it appears at the top and there is more Thai text on the sign? Or is English preferred since the text in English is in a larger font?

The sign in Figure 19 is endorsed by AIs (a Thai telecommunications company) with logo and text in English and Thai, though not pertaining to single use plastic. However, the preferred code on the sign is Thai as the instructions are written with Thai in the upper position and English in the lower. Yet, the signs in Figures 15, 18 and 19 draw attention to the branding of Thammasat's green discourse campaign, Thammasat Smart City (Figure 18) and Thammasat People \& Sustainability (Figures 15 and 19), both of which are in English. We can also observe the green Dome outline in Figure 15 and the Thammasat seal emblem in Figures 15 and 19. The presence of the logo for Thammasat Smart City and Thammasat People \& Sustainability on many of its green discourse signs homogenizes the discourse around the campaign making it high scale, while at the same time localizing the practice to a particular place, Thammasat University. Again, the notion of polycentricity in terms of whose voice of authority is driving this campaign emerges. Here we have the university, two corporate entities, and one sign made by students. The voices of the creators of these signs are interesting in terms of scale. The students should represent localized voices but they chose to use English to disseminate their message in 
Figure 17. This behavior in language choice in green discourse indexes how this discourse is globalized in English.

The images in Figures 20 and 21 denote objects that materialize green discourse beyond just text and infographics. Recently Ledin and Machin (2018) have noted the need for a materialized critical multimodal discourse analysis that goes beyond just a mere identification of metafunctions and what they dub grand theory multimodality to include the materiality of multimodal critical discourse. Here materiality can be discussed in terms of objects in the material world that iconically represent ideological stances to green discourse at Thammasat University. The icon of the Dome adorned with solar panels and a campaign to buy Dome water both exemplify how objects can be used to iconize ideology.

Part of the discourse here is how objects can have meaning without having text on them. People familiar with Thammasat would be immediately aware that the object in Figure 21 is a reference to the Dome. Adorning the Dome in solar panels indexes notions of green discourse while at the same time using the Dome as a voice of authority. In this manner, objects can index scale as well.

In this section I have shown examples of the green discourse that has emerged at Thammasat University. Much of the green discourse invokes a

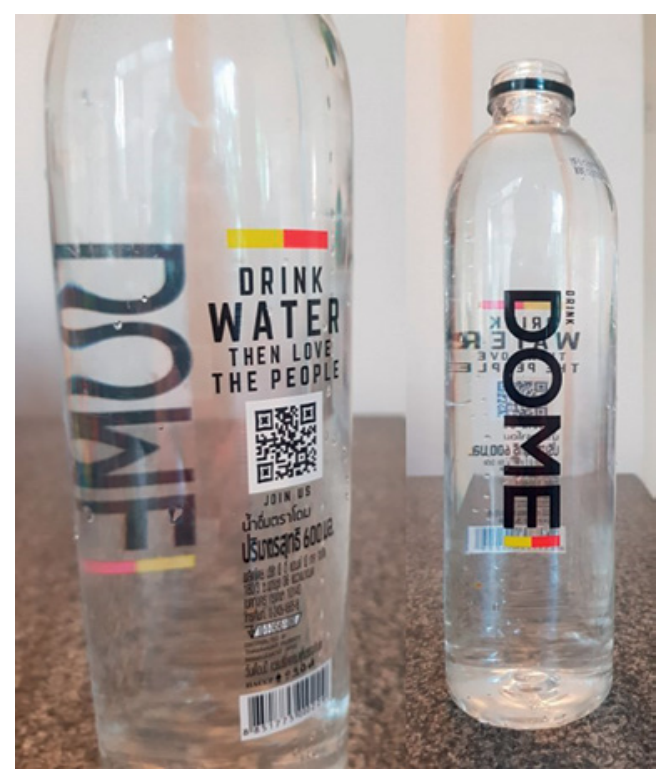

FIGURE 20

Drink water then love the people 


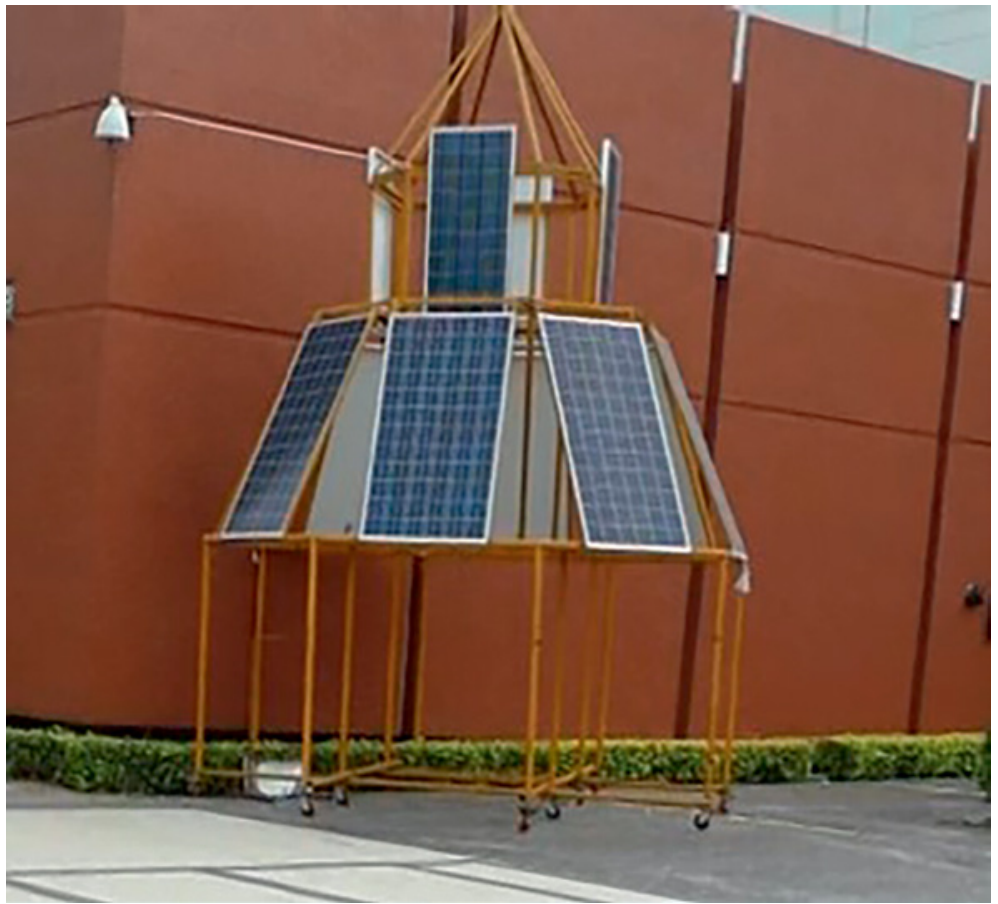

FIGURE 21 The Dome with solar panels

higher scale through homogenized linguistic tokens (e.g. single use plastic, green). These texts also represent different indexical orders in how they denote and connote references to the environment and sustainability. The texts also illustrate the problem of polycentricity in terms of who, or what, the voice of authority is, that these texts are speaking to. The overwhelming presence of English and its code preference in many of these signs reflect language of globalization.

\section{Student Perceptions of Green English}

In the previous section I analyzed the text on signs regarding green discourse arguing that such signs reflect a higher scale because of the presence of such tokens that reflect globalization. One issue with studies of linguistic landscapes is that they are often only based on such textual analyses. One way to triangulate such studies is by interviewing the perceived audience or users of such signage. Walking interviews have been one method applied to linguistic 
landscapes to illustrate how the linguistic landscape is involved in place making itself (Stroud and Jegels 2014; Troyer and Szabó 2017; Lou 2017). To augment the data discussed in the previous section 15 students were interviewed during walking tours at the Thammasat University Rangsit Center Campus. During the tour students were asked to comment on the sustainability signage in the $\mathrm{SC}_{2}$ building, and here the findings from those walking interviews are discussed. The focus of the interviews was on three signs: figures 1, 2 and 5 . However for the purposes of space, analytical attention will focus upon comments regarding Figures 1 and 2 . These signs were chosen for further discussion because of their ambiguity as well as their ease of access along the walking tour. The students were asked the following questions on each sign: what do they believe the sign means and why does it appear in that particular location? In what follows I discuss some themes that emerged from the discussions with students about these signs.

Excerpts 1 and 2 were typical of the 15 students who were interviewed about Figure 1 . They noted difficulty in understanding $22 \%$, which is evidenced in the use of rising intonation that denotes a question. In excerpt 1 , Bow uses questions in four of the five lines, two are with rising intonation, before concluding that she does not know what they are saying here. In excerpt 2 we effectively observe the same discursive use of questioning the $22 \%$ with rising intonation.

\section{Excerpt 1}

1. Bow: 22 percent?

2. Int: yeah

3. why don't they: just let just the red one?

4. $\quad$ why did they put the article in there?

5. $\quad<$ reading $>$ more energy efficient compared with typical education?

6. I don't understand what they're saying

In Bow's discussion of Figure 1 she notes outright that she did not understand the text on the sign. The reference to "red one" in line 3 is asking why did they not just leave that part of the building red why put text on it? In addition, the use of the pronoun they in lines 3, 4 and 6 is interesting to consider in terms of polycentricity as they would be reflective of a voice of authority which we assume to be the institution. Nan in excerpt two has a similar reaction to Figure 1 and here I wish to point out Nan's use of rising intonation as a question in line 2 huh? which indexes her lack of comprehension of the text. 
Excerpt 2

1. Nan: 22 percent? < reading under her breath>

2. huh?

3. I have no idea about what this means

Excerpt three is slightly different than the previous two, here Chan offers many instances of hedging in lines 2 through 5 and line 7 . He uses a question with rising intonation in line 6 . In short, the use of questions with rising intonation as well as his use of hedging suggests the confusion that participants had in understanding the sign in figure 1.

\section{Excerpt 3}

1. Chan: < reading > more energy efficient hm compared with typical educational buildings

2. maybe they

3. want the student to like

4. at least uh

5. $\quad$ when they

6. when they get out of the room after they study?

7. th-th-they turn off the light or something like that

8. $\quad$ so they write the big sign

Excerpts 4 and 5 examine Figure 2. Tookata in excerpt 4 also identifies how the university is promoting itself as ecofriendly in lines 7 and 8. In terms of how she comprehends the message in Figure 2, she believes that it is referencing trees planted near the building (line 5 ).

\section{Excerpt 4}

1. Tookata: green area hmm. .

2. I think they put this one

3. near

4. Int: near the building

5. Tookata: near the building and near the tree

$6 . \quad$ just

7. promote our university

8. eco friendly university 
Uey's discussion of Figure 2 in excerpt five is similar to excerpt 4 , she emphasizes that the university is promoting saving the environment and green spaces (lines 6, 7 and 13). As Schiffrin (1987) notes the discourse marker you know operates in the information state. Uey's use of the discourse marker you know performs the function of emphasizing the information she is displaying regarding the university and the environment.

\section{Excerpt 5}

1. Int: tell me about this one

2. Uey: green area 1 tree per open space

3. so

4. this sign

5. okay

6. $\quad$ so our university promoting this you know

7. saving the environment

8. $\quad$ and here

9. it's a green area pointing to the area in front of the sign

10. Int: the green

11. Uey: and what they doing is a planting plants to

12. you know

13. to increase more green spaces in the university

What I find interesting about excerpts 4 and 5 concerning Figure 2 was how the signs index, and discursively construct, a local institutional identity. The students are aware that Thammasat is promoting notions of sustainability and environmentalism despite the vague referents about what the sign is referring to. Here we see how just a textual analysis of the signs in the linguistic landscape can be inadequate. For the students, not knowing if Green area: 1 tree per open space $100 \mathrm{~m}^{2}$ refers to the building's immediate surroundings or in general, is not as important as this sign being a marker of institutional identity that links the university to sustainability and environmentalism on a global level. The notion of sociolinguistic scale has been used to emphasize how signs like Figures 1 and 2 reflect a homogenous higher scale in the textual analysis. However, for the students, they identify the sign as indexing institutional identity. To a degree the sign is more localized in terms of its meaning, and thus reflective of a lower scale for the students who identify it with the institution. But outsiders not familiar with the local institutional identity may still perceive the signs reflecting a higher scale. 
In the last excerpt I will discuss from the interview data, a student Bpu is talking about why he thinks that English is used on the signage in the building SC 2. He raises two issues regarding English relevant to the textual analysis: English is cool and fashionable and that English reflects things that are international.

\section{Excerpt 6}

1. Int: so why do you think they put all those stuff in English though?

2. Bpu: in English

3. Int: yeah none of these is in Thai

4. Bpu: uhm

5. for me na for me

6. its looks cool

7. Int: it looks it looks cool?

8. Bpu: yeah it looks cool more than Thai

9. Int: Okay

10. Bpu: like when it becomes like an international campaign

11. it should be in English

12. I don't know why but its fashionable

13. Int: so

14. stuff about the environment is international?

15. Bpu: yeah

This notion of the fashion-ability or chic-ness of English in Thailand has been documented (Troyer 2012) but its use on signs regarding green discourse on a global level is also interesting to consider in another sense. Namely how such particular uses are not just reflective of a Global English, but also reflect what Rodney Jones (2016) and Freek Olaf de Groot (this issue) refer to as technologies of talk. Such technologies of talk are tools from languages such as English to gesture and ways of speaking. As a technology of talk, the use of English on environmental discourse at this university performs a number of actions aligning the texts to: environmentalism, the chic-ness of English, higher sociolinguistic scales, institutional identity, institutional branding, not to mention globalization itself.

This survey of language choice in the signs that represent green discourse at Thammasat University has discussed how English emerges as the preferred 
code. Otherwise, Thai is the preferred code for language use at this university. Why is English the preferred code for indexing green discourse at a Thai university when Thai is more often the language that is used to represent place? One way to explain this use of English is that English in Thailand is used to represent a trendy-ness or chic-ness (Troyer 2012). Whereby notions such as environmentalism, sustainability and what I refer to as green discourse have a novelty to them in Thailand such that English is used to express a stance that is green. Another way to answer this question is to emphasize how environmentalism is a part of globalization. To accomplish this task, I have drawn attention to several concepts from Blommaert's (2010) discussion of the sociolinguistics of globalization. The presence of English as the preferred code for green discourse indexes several sociolinguistic patterns: one that English is a discourse that exists on a higher scale which homogenizes the language used to explain environmental issues; second in terms of orders of indexicality the language that is used in green discourse at Thammasat indexes both local and global senses of environmentalism (e.g. single use plastic, solar panels, the presence of Thai English); lastly the voices of authority that are represented in these signs are varied. In some cases, the voice of authority is localized in branding: Thammasat Smart City, Thammasat People \& Sustainability, the Dome icon and the Thammasat seal. In other instances, the voice of authority is more global, for example references to single use plastic as well as many of the infographics and signs in the new building SC2 (Figures 1, 2, $3,4,5,6,7,8$ ). These varied voices of authority (what Blommaert refers to as polycentricity) problematize the green discourse on signs at Thammasat in terms of globalization. In sum I argue that the preference for English on signs that index green discourse is a symptom of processes of globalization the world over.

\section{Acknowledgements}

The data reported on here were collected as a part of Thammasat University Faculty of Liberal Arts Research Funds from the fiscal year of 2019, Grant \# 13/256, Narrativizing the Linguistic and Semiotic Landscape of a Thai University: A Nexus Analysis of Thai English and Linguistic Landscapes.

\section{References}

Al-Mutairi, Fahad. 2014. The Minimalist Program: The Nature and Plausibility of Chomsky's Biolinguistics. Cambridge: Cambridge University Press. 
Alexander, Richard and Arran Stibbe. 2014. From the Analysis of Ecological Discourse to the Ecological Analysis of Discourse. Language Sciences 41: 104-110.

Appadurai, Arjun. 1996. Modernity at Large: Cultural Dimensions of Globalization. Minneapolis, MN: University of Minnesota Press.

Blommaert, Jan. 2007. Sociolinguistic scales. Intercultural Pragmatics 4.1: 1-19.

Blommaert, Jan. 2010. The Sociolinguistics of Globalization. Cambridge: Cambridge University Press.

Blommaert, Jan. 2015. Chronotopes, Scales, and Complexity in the Study of Language in Society. Annual Review of Anthropology 44.1: 105-116.

Boeckx, Cedric and Pedro Tiago Martin. 2016. Biolinguistics. Oxford Research Encyclopedia of Linguistics. https://doi.org/10.1093/acrefore/9780199384655.013.20.

Chen, Sibo. 2016. Language and Ecology: A Content Analysis of Ecolinguistics as an Emerging Research Field. Ampersand 3: 108-116.

de Groot, Freek Olaf. 2019. Language Choice as a Technology of Talk: A Case Study of Thai Teacher Trainees. Manusya:Journal of Humanities 23.3.

Dryzek, John S. 2013. The Politics of the Earth:Environmental Discourses. Oxford: Oxford University Press.

Erickson, Frederick. 2004. Talk and Social Theory: Ecologies of Speaking and Listening in Everyday Life. Hoboken, NJ: Wiley.

Erickson, Frederick. 2015. Oral Discourse as a Semiotic Ecology the Co-construction and Mutual Influence of Speaking, Listening, and Looking. In The Handbook of Discourse Analysis, Edited by Deborah Tannen, Heidi E. Hamilton and Deborah Schiffrin, pp. 422-446. New York:John Wiley \& Sons, Ltd.https://doi.org/10.1002/9781118584194 .ch2o.

Fairclough, Norman. 1992. Intertextuality in Critical Discourse Analysis. Linguistics and Education 4.3-4: 269-293.

Gee, James Paul. 2015. Discourse, Small d, Big D. In The International Encyclopedia of Language and Social Interaction. John Wiley \& Sons, Inc. https://doi.org/10.1002/ 9781118611463.wbielsio16.

Goffman, Erving. 1981. Forms of Talk. Philadelphia: University of Pennsylvania Press.

Halliday, Michael Alexander Kirkwood. 2001. "New Ways of Meaning: The Challenge to Applied Linguistics." In The Ecolinguistics Reader: Language, Ecology, and Environment, 175-202. New York: Continuum.

Harré, Rom, Jens Brockmeier and Peter Mühlhäuser. 1999. Greenspeak: A Study of Environmental Discourse. Thousand Oaks, CA: Sage Publications.

Haugen, Einar. 1972. The Ecology of Language. Stanford, CA: Stanford University Press. Huebner, Thom. 2006. Bangkok's Linguistic Landscapes: Environmental Print, Codemixing, and Language Change. In Linguistic Landscape: A New Approach to Multilingualism, Edited by Durk Gorter, pp. 31-51. Clevedon: Multilingual Matters. 
Hult, Francis. M. 2009. Language Ecology and Linguistic Landscape Analysis. In Linguistic Landscape: Expanding the Scenery, Edited by Elana Shohamy and Durk Gorter, pp. 88-104. New York: Routledge.

Iedema, Rick. 2001. Resemiotization. Semiotica 137: 23-39.

Jaworski, Adam. 2015. Globalese: A New Visual-Linguistic Register. Social Semiotics 25.2: 217-35. https://doi.org/10.1080/10350330.2015.1010317.

Jenkins, Lyle. 200o. Biolinguistics: Exploring the Biology of Language. Cambridge: Cambridge University Press. https://doi.org/10.1017/CBO9780511605765.

Jones, Rodney Hale. 2016. Spoken Discourse. London, England: Bloomsbury Publishing. Kress, Gunther, and Theo van Leeuwen. 1996. Reading Images: The Grammar of Visual Design. London: Routledge.

Landry, Rodrique and Richard Y. Bourhis 1997. Linguistic Landscape and Ethnolinguistic Vitality: An Empirical Study. Journal of Language and Social Psychology 16.1: $23-49$.

Ledin, Per and David Machin. 2018. Doing Critical Discourse Studies with Multimodality: from Metafunctions to Materiality. Critical Discourse Studies 16.5: 497-513. https://doi.org/10.1080/17405904.2018.1468789.

LeVasseur, Todd. 2015. Defining “Ecolinguistics?”: Challenging Emic Issues in an Evolving Environmental Discipline. Journal of Environmental Studies and Sciences 5.1: 21-28.

Lou, Jackie Jia. 2017. Spaces of Consumption and Senses of Place: A Geosemiotic Analysis of Three Markets in Hong Kong. Social Semiotics 27.4: 513-31. https://doi.org/10 $.1080 / 10350330.2017 .1334403$.

Mansvelt, Juliana. 2011. Green Consumerism: An A-to-Z Guide. New York: SAG E.

Nettle, Daniel and Suzanne Romaine. 200o. Vanishing Voices: The Extinction of the World's Languages. Oxford: Oxford University Press.

Sanz, Montserrat, Itziar Laka, and Michael K. Tanenhaus (Eds.). 2013. Language down the Garden Path: The Cognitive and Biological Basis for Linguistic Structures. Oxford: Oxford University Press.

Schiffrin, Deborah. 1987. Discourse Markers. Cambridge: Cambridge University Press. https://doi.org/10.1017/CBO9780511611841.

Scollon, Ron and Suzanne Wong Scollon. 2003. Discourses in Place: Language in the Material World. Abingdon, UK: Taylor \& Francis.

Scollon, Ron and Suzanne Wong Scollon. 2004. Nexus Analysis Discourse and the Emerging Internet. New York: Routledge.

Scollon, Ron and Suzanne Wong Scollon. 2007. Nexus analysis: Refocusing Ethnography on Action. Journal of Sociolinguistics 11.5: 608-625.

Scollon, Ron, Suzanne Wong Scollon and Rodney H. Jones. 2012. Intercultural Communication: A Discourse Approach (3rd ed). Malden, MA: Wiley-Blackwell. 
Silverstein, Michael. 2003. Indexical Order and the Dialectics of Sociolinguistic Life. Language \& Communication 23: 193-229.

Smalley, William. A. 1994. Linguistic Diversity and National Unity: Language Ecology in Thailand. Chicago, IL: University of Chicago Press.

Stibbe, Arran. 2014. An Ecolinguistic Approach to Critical Discourse Studies. Critical Discourse Studies 11.1: 117-128.

Stroud, Christopher and Dmitri Jegels. 2014. Semiotic Landscapes and Mobile Narrations of Place: Performing the Local. International Journal of the Sociology of Language 228: 179-99. https://doi.org/10.1515/ijsl-2014-0010.

Troyer, Robert. A. 2012. English in the Thai Linguistic Netscape. World Englishes 31.1: 93-112.

Troyer, Robert A. and Tamás Péter Szabó. 2017. Representation and Videography in Linguistic Landscape Studies. Linguistic Landscape: An International Journal 3.1: 56-77. https://doi.org/10.1075/ll.3.1.o3tro.

Urban, Gregory and Michael Silverstein. 1996. Natural Histories of Discourse. Chicago, IL: University of Chicago Press.

Wei, Li. 2018. Translanguaging as a Practical Theory of Language. Applied Linguistics 39.1: 9-30. https://doi.org/10.1093/applin/amxo39. 